\title{
DAMPAK LIBERALISASI PERDAGANGAN TERHADAP TINGKAT EMPLOYMENT DAN UPAH PADA INDUSTRI MANUFAKTUR PADAT KARYA DI INDONESIA *
}

\author{
Joko Susanto ${ }^{1}$ \\ Purwiyanta ${ }^{1}$ \\ ${ }^{1}$ Fakultas Ekonomi Universitas Pembangunan Nasional "Veteran" Yogyakarta
}

\begin{abstract}
In line with trade liberalization, all of trade barrier such as tariff and non-tariff barrier would be reduced. Indonesia would go into a free trade era. The objective of research is to investigate short and long run effect of trade liberalization on employment and wages of labor-intensive industries.

By regressing based on panel data, the results show that trade liberalization via tariff reducing would raise the employment and wage of labor intensive industries in the short and long run. Tariff reduction increases demand for the economy's abundant factor (labor), driving wages higher. In the long run, capital is mobile between sectors, generates the higher of capital. The higher of capital implies of an increasing marginal product of labor, driving wages higher.
\end{abstract}

Keywords: trade liberalization, tariff reducing, employment, wage, labor intensive industries

\section{PENDAHULUAN}

Dengan masuknya Indonesia dalam Organisasi Perdagangan Dunia (WTO), maka segala macam hambatan perdagangan luar negeri Indonesia baik yang berupa tarif maupun non tarif akan dihilangkan (Departemen Luar Negeri, 2003). Indonesia akan menghadapi era perdagangan bebas yang ditandai dengan tidak adanya lagi hambatan perdagangan. Terjadinya perdagangan bebas akan meningkatkan persaingan.
Produk Indonesia akan bersaing langsung dengan produk serupa dari negara lain dan sebaliknya. Peningkatan persaingan tidak hanya berdampak pada komposisi sektor barang (distribusi sektor ekspor dan impor), tetapi juga berdampak langsung pada kelangsungan hidup perusahaan/industri. Perusahaan yang efisien akan terus dapat melakukan kegiatannya. Sebaliknya perusahaan yang tidak efisien akan menghadapi kemungkinan untuk rugi dan akhirnya

\footnotetext{
* Penelitian ini pernah dipresentasikan penulis dalam International Conference on Economy and Business, tanggal 14 sampai dengan 15 Desember 2005 di Solo, yang diselenggarakan oleh Universitas Muhammadiyah Surakarta bekerja sama dengan Universiti Kebangsaan Malaysia.
} 
meninggalkan pasar. Keluarnya perusahaan dari pasar akan mengakibatkan permasalahan employment yaitu menganggurnya faktor produksi yang tadinya digunakan untuk kegiatan produksi, termasuk faktor produksi tenaga kerja.

Dampak liberalisasi perdagangan terhadap tingkat employment, akan bergantung pada keseimbangan struktural dan efek efisiensi (distribusi output antar perusahaan dan imbalan bagi pemilik faktor produksi). Dampak liberalisasi perdagangan akan menyangkut dampak dalam jangka panjang dan jangka pendek. Perbedaan dampak jangka pendek dan panjang dari liberalisasi perdagangan terhadap tingkat employment dan upah terkait dengan proses penyesuaian dan macam kebijakan yang diambil. Perbedaan yang tcrjadi akan bergantung derajat mobilitas faktor produksi, daya saing, struktur organisasi dan kecepatan penyesuaian tingkat upah dan employment menuju equilibrium (Haouas, dkk, 2002).

Studi yang dilakukan oleh Wood (1994) menunjukkan bahwa pergeseran strategi pembangunan negara sedang berkembang dari substitusi impor menuju promosi ekspor, meningkatkan kinerja industri padat karya dan sekaligus meningkatkan permintaan terhadap faktor produksi tenaga kerja. Hasil penelitian ini konsisten dengan hipotesis bahwa integrasi negara berkembang ke perekonomian dunia akan diikuti dengan menurunnya kesenjangan pendapatan (income inequalities) dan meningkatnya employment (Krueger, 1990 dalam Arbache, 2001). Harga input yang berlimpah (upah) akan naik. Kenaikan tingkat upah ini konsisten dengan teori Heckser Ohlin. Peningkatan upah akan berdampak negatif terhadap daya saing (competitiveness) sektor industri.

Sebagaimana negara berkembang lainnya, Indonesia mengikuti strategi pembangunan industri substitusi impor sampai dengan menjelang era perdagangan bebas. Struktur proteksi yang dibangun selama beberapa waktu dan kebijakan perdagangan luar negeri, akan menentukan arah alokasi sumber daya. Arah alokasi sumber daya sangat rentan terhadap proteksi dan nilai tukar. Berbagai kebijakan yang dilakukan pemerintah cenderung mendistorsi harga dan alokasi sumber daya menjadi tidak efisien. (Poot, dkk, 1992; 16). Sebagai akibatnya alokasi sumber daya dan rate of returns akan berbeda bila terjadi liberalisasi perdagangan.

Beberapa studi empiris menunjukkan bahwa liberalisasi perdagangan di beberapa negara berasosiasi dengan meningkatnya returns dari human capital dan memburuknya distribusi upah. Sebagai negara berkembang, Indonesia berlimpah dengan unskilled labor. Sesuai dengan teori ekonomi standar, negara berkembang akan berspesialisasi pada produksi barang dan jasa yang menggunakan unskilled labor secara intensif. Permintaan terhadap unskilled labor naik dan sehingga upah naik (Markusen dkk, 1995; 109).

Kelompok industri padat karya mampu melakukan ekspor dengan nilai relatif tinggi. Sebagian besar komoditas ekspor indonesia berasal dari kelompok industri tersebut. Industri yang melayani kebutuhan luar negeri cenderung memiliki rata-rata pekerja per perusahaan yang tinggi. Hal ini menunjukkan bahwa ekspor cenderung bertumpu pada keunggulan tenaga kerja, khususnya upah yang rendah (Setiaji, 2001; 79). Sebagian 
besar industri padat karya berupa industri makanan, sandang, dan pengolahan kayu.

Liberalisasi perdagangan yang berupa penurunan tarif dimulai dengan masuknya IMF ke Indonesia pada tahun 1998 guna mengatasi krisis ekonomi. Di antara program IMF tersebut adalah penurunan tarif untuk berbagai komoditas. Selanjutnya untuk keperluan harmonisasi tarif dan peningkatan daya saing perekonomian dalam negeri, maka pemerintah melalui menteri keuangan mengeluarkan Keputusan Mcnteri Keuangan RI. No: 502/KMK.01/1998. Melalui surat keputusan tersebut pemerintah menurunkan bea masuk atas impor beberapa produk tertentu. Tarif rata-rata mengalami penurunan yang drastis dari rata-rata tarif sebesar 9,34 persen tahun 1998 menjadi 7,23 persen pada tahun 2003. Jumlah tarif yang telah diturunkan hingga 0,5 persen telah mencapai 80 persen pos tarif. Penurunan tarif akan berdampak terhadap tingkat employment dan upah pekerja industri manufaktur padat karya.

Permasalahan dalam penelitian ini dirumuskan: Bagaimana dampak liberalisasi perdagangan terhadap tingkat employment dan upah pada industri manufaktur padat karya di Indonesia baik jangka pendek maupun jangka panjang.

Penelitian ini bertujuan untuk mengetahui dampak liberalisasi perdagangan terhadap tingkat employment dan upah pada industri manufaktur padat karya di Indonesia baik jangka pendek maupun jangka panjang.

\section{RERANGKA TEORI DAN PENELITIAN SEBELUMNYA}

\section{Rerangka teori}

Penelitian tentang penyesuaian pasar tenaga kerja terhadap liberalisasi perdagangan untuk negara kecil dilakukan antara lain oleh Edward (1988). Dalam penelitian ini faktor produksi dibagi menjadi dua macam yaitu modal (K) dan tenaga kerja (L). Kedua macam input tadi dikombinasikan dalam fungsi produksi untuk menghasilkan output. Liberalisasi perdagangan akan berdampak terhadap output industri baik jangka pendek maupun panjang.

Dampak jangka pendek dari liberalisasi perdagangan terjadi pada kurun waktu dimana faktor produksi modal tidak dapat bergerak bebas antar sektor (immobile) sedangkan dalam jangka panjang faktor produksi modal bergerak bebas antar sektor (mobile). Sedangkan tenaga kerja dapat bergerak antar sektor baik dalam jangka pendek maupun jangka panjang. Diasumsikan perekonomian tidak melakukan spesialisasi secara penuh dalam sisi produksi.

\section{a. Dampak Liberalisasi Perdagangan dalam Jangka Pendek}

Dalam jangka pendek modal tidak dapat bergerak bebas antar sektor, sedangkan tenaga kerja dapat bergerak antar sektor. Penurunan harga barang impor (akibat penurunan tarif) akan mengakibatkan peningkatan jumlah barang yang diminta. Produsen domestik akan meningkatkan outputnya dengan menambah faktor produksi tenaga kerja. Akan tetapi karena modal tidak dapat bergerak bebas antar sektor, maka dalam jangka pendek tidak terjadi peningkatan jumlah faktor produksi modal. Penambahan jumlah tenaga kerja tanpa diikuti penambahan faktor produksi modal akan berdampak terhadap menurunnya produk marjinal tenaga kerja (Haouas, dkk, 2002). Dengan asumsi bahwa upah dibayar 
sesuai dengan nilai produk marjinal, maka penurunan produk marjinal tenaga kerja berarti penurunan tingkat upah. Dengan demikian, dalam jangka pendek penurunan tarif akan meningkatkan jumlah produksi dan employment, tetapi menurunkan upah pekerja.

\section{b. Dampak Liberalisasi Perdagangan dalam Jangka Panjang}

Dalam model negara kecil terbuka, ketika faktor produksi dapat bergerak bebas antar sektor, maka berlaku ketentuan:

- Harga barang dunia, teknologi dan tarif menentukan harga domestik

- Akan tercapai harga equilibrium, harga dunia barang ekspor dan impor menentukan pendapatan faktor produksi

Dalam jangka panjang penurunan harga barang akibat liberalisasi perdagangan akan berlangsung seperti yang diprediksi oleh teori StolperSamuelson. Dengan barang ekspor yang relatif padat tenaga kerja, penurunan tarif akan menaikkan permintaan terhadap barang produksi padat karya sehingga output industri padat karya naik. Kenaikan output memerlukan jumlah tenaga kerja yang lebih banyak sehingga permintaan tenaga kerja naik dan diikuti kenaikan upah (Markusen dkk, 1995; 109). Dalam jangka panjang, faktor produksi modal dapat bergerak antar sektor sehingga jumlah modal akan bertambah. Kenaikan jumlah modal ini akan meningkatkan produk marjinal tenaga kerja sehingga meningkatkan tingkat upah (Haouas, dkk, 2002).

\section{Penelitian sebelumnya}

Studi empiris mengenai dampak liberalisasi perdagangan di negara berkembang menunjukkan bahwa liberalisasi perdagangan akan meningkatkan permintaan terhadap skilled labor dan meningkatkan kesenjangan upah sehingga menolak teori Heckser Ohlin dan Stolper- Samuelson.

Robbin (1994) mengamati perubahan struktur upah setelah liberalisasi perdagangan di Chili menemukan bahwa walaupun kandungan skilled labor dalam produk impor melebihi produk ekspor, pendapatan skilled labor meningkat seiring dengan liberalisasi perdagangan. Selanjutnya Robbin (dalam Arbache 2001) meneliti perubahan tingkat upah di Colombia sebagai respon dari peningkatan ekspor akibat devaluasi dan peningkatan proporsi impor barang modal terhadap Gross Domestic Product (GDP). Robbin menemukan adanya peningkatan kesenjangan upah akibat adanya korelasi positif antara peningkatan impor mesin, peralatan dan masuknya teknologi baru dengan peningkatan permintaan terhadap skilled labor.

Robbin dan Glinding (1999) mengkaji perubahan upah relatif dan penawaran serta permintaan skilled labor di Costa Rica sebelum dan sesudah liberalisasi perdagangan, menemukan bahwa premi untuk skilled labor setelah liberalisasi meningkat akibat perubahan struktur permintaan tenaga kerja. Beyer, Rojas dan Vergara (1999) dengan menggunakan data time series menemukan adanya hubungan jangka panjang antara keterbukaan/liberalisasi dengan kesenjangan upah di Chili. 


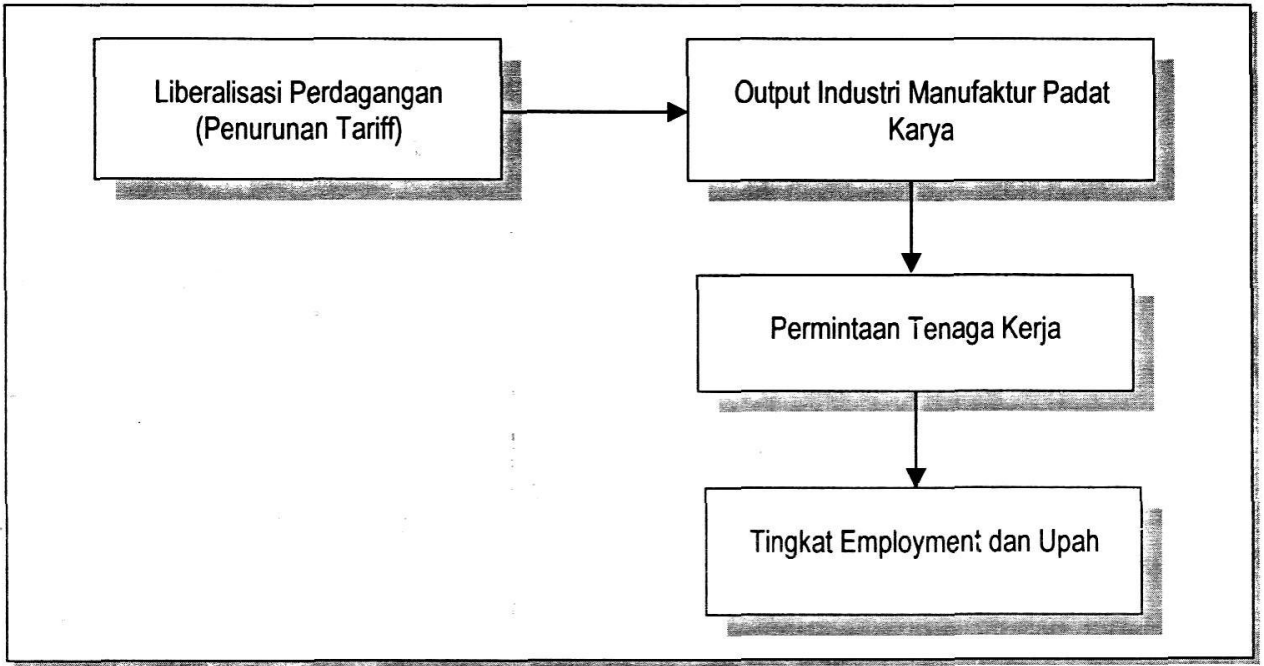

Diagram 1. Desain Penelitian

Penelitian yang dilakukan oleh Lee (1999) menganalisis pentingnya reformasi, pengembangan pasar dalam penentuan upah dan employment pada sektor perusahaan negara di Cina. Pasar tenaga kerja pada sektor ini berbeda perilakunya dibanding sektor pedesaan. Hasil penelitian menunjukkan bahwa korporasi akan menurunkan upah dan meningkatkan produktivitas, akan tetapi tidak mengakibatkan perubahan yang signifikan pada employment. Tingkat upah dan employment berkorelasi positif dengan produktifitas dan rasio faktor produksi (K/L). Pekerja non produksi memiliki respon yang lebih besar dibanding pekerja produksi.

Levinsoln (1999) menganalisis respon employment terhadap liberalisasi perdagangan di Chili dengan data berbasis perusahaan. Pola job creation dan job destruction berhubungan dengan ukuran perusahaan dan orientasi pemasaran. Hasil penelitian ini menunjukkan bahwa ukuran perusahaan berperan penting. Shock ekonomi makro akan berdampak pada perusahaan impor dan ekspor secara sama. Reformasi nilai tukar mempunyai dampak yang berbeda. Dampak secara bersama dari gejolak ekonomi makro dan liberalisasi perdagangan mengakibatkan penurunan tingkat employment pada sektor industri manufaktur sebesar 8 persen.

\section{HIPOTESIS PENELITIAN}

Penelitian ini mengajukan hipotesis berikut. Liberalisasi perdagangan dalam jangka pendek akan menaikkan employment dan menurunkan upah pekerja, sedangkan dalam jangka panjang liberalisasi perdagangan akan menaikkan employment dan upah pekerja industri manufaktur padat karya.

\section{DESAIN PENELITIAN}

Desain penelitian adalah seperti terlihat pada diagram 1.

Liberalisasi perdagangan yang berupa penurunan tarif akan berdampak terhadap kinerja (tingkat output) industri manufaktur padat karya. Oleh karena permintaan tenaga 
kerja merupakan permintaan turunan (derived demand) dari tingkat output industri, maka kinerja industri ini akan berpengaruh terhadap permintaan faktor produksi tenaga kerja. Perubahan permintaan tenaga kerja akan berdampak terhadap tingk : employment dan upah pekerja.

\section{METODE PENELITIAN}

\section{Data dan sumber data}

Penelitian ini menggunakan data sekunder yang bersumber dari publikasi Badan Pusat Statistik (BPS) dan instansi lain yang relevan. Secara garis besar data penelitian akan mencakup nilai output, tingkat upah, jumlah tenaga kerja untuk sektor industri manufaktur padat karya. Penelitian ini akan mencakup sepuluh besar industri padat karya yaitu industri minyak kasar, gula pasir, pengolahan teh, pengolahan tembakau dan bumbu rokok, rokok kretek, pemintalan benang, pertenunan, perajutan, pakaian jadi, dan kayu lapis

\section{Pembentukan model}

Dalam penelitian ini diasumsikan model fungsi produksi industri manufaktur adalah CES (Constant Elasticity Substitution). Model fungsi produksi CES mengasumsikan elastisitas substitusi antar faktor produksi konstan akan tetapi tidak mesti sama dengan satu. Mengamati fenomena yang terjadi pada industri manufaktur di Indonesia, maka substitusi antara kapital dan tenaga kerja tidak mudah untuk dilakukan. Untuk menghasilkan output tertentu dapat digunakan kombinasi terbatas dari kapital dan tenaga kerja. Ini berkaitan dengan teknologi yang digunakan. Elastisitas substitusi antara modal dan tenaga kerja cenderung konstan. Dengan demikian teori dan model fungsi produksi yang dipandang sesuai adalah model fungsi produksi CES. Formulasi fungsi produksi CES adalah sebagai berikut.

$\mathrm{Q}=\gamma\left[\delta \mathrm{K}^{-\rho}+(1-\delta) \mathrm{L}^{-\rho}\right]^{-\mathrm{v}} / \rho$

dimana $Q$ adalah output

$\mathrm{K}$ adalah input

$\mathrm{L}$ adalah tenaga kerja

Produk marjinal dapat dituliskan sebagai

$\mathrm{MP}_{\mathrm{L}}=\frac{\mathrm{v}(1-\delta)}{\gamma^{(\rho / v)}} \cdot \frac{\mathrm{Q}^{(1+\rho / v)}}{\mathrm{L}^{(1+\rho)}}$

Perusahaan yang memaksimumkan laba akan menggunakan tenaga kerja dan modal pada tingkat di mana produk marjinal dari tenaga kerja sama dengan upah $\left(\mathrm{MP}_{\mathrm{L}}=\mathrm{w}\right)$. Dengan asumsi ini serta melalui penulisan dalam bentuk In, dapat dibangun model berikut (Kim,1984;146-147).

$\operatorname{Ln}(\mathrm{Q} / \mathrm{L})=\mathrm{b} 1+\mathrm{b} 2 \operatorname{Ln} w+b_{3} \operatorname{Ln} \mathrm{Q}$

$\operatorname{Ln} L=-b_{1}-b_{2} \operatorname{Ln} w+\left(1-b_{3}\right) \operatorname{Ln} Q$

$\operatorname{Ln} \mathrm{L}=\alpha_{1}+\alpha_{2} \operatorname{Ln} \mathrm{w}+\alpha_{3} \operatorname{Ln} \mathrm{Q}$

Persamaan (4) merupakan permintaan tenaga kerja

Upah ditentukan oleh fungsi invers penawaran tenaga kerja dan beberapa faktor lain di antaranya tingkat upah periode sebelumnya. Persamaan tingkat upah dapat dituliskan sebagai

$\operatorname{Lnw}_{t}=\beta_{\mathrm{o}}+\beta_{1} Q_{t}+\beta_{2} \operatorname{Ln} L_{t}+\beta_{3} \operatorname{Ln}_{t-1}$ 
Oleh karena observasi meliputi beberapa industri selama beberapa periode, maka estimasi dilakukan berdasar panel data. Penggunaan panel data mempunyai keunggulan dibanding dengan data time series atau cross section biasa. Penggunaan panel data akan menaikkan derajat kebebasan (degree of freedom) dan mengurangi kolinieritas di antara variabel penjelas sehingga menghasilkan koefisien estimasi yang efisien (Hsiao, 1995). Di samping itu panel data memungkinkan untuk mengontrol heterogenitas individual serta lebih mampu mengamati dinamika penyesuaian (Baltagi, 2000, 5). Selanjutnya dari persamaan (4) dan (5) dapat dibangun model dinamis dengan memberikan lag terhadap variabel dependen dan independen.

$$
\begin{aligned}
\Delta \operatorname{Ln~} \mathrm{L}_{\mathrm{it}}= & \beta_{\mathrm{o}}+\beta_{1} \Delta \operatorname{Ln} \mathrm{L}_{\mathrm{it}-\mathrm{I}}+\beta_{2} \Delta \mathrm{Ln} \mathrm{w}_{\mathrm{it}}+ \\
& \beta_{3} \Delta \operatorname{Ln~w~}_{\mathrm{it}-1}+\beta_{4} \Delta \operatorname{Ln} \mathrm{Q}_{\mathrm{it}}+ \\
& \beta_{5} \Delta \operatorname{Ln} \mathrm{Q}_{\mathrm{it}-\mathrm{1}}+\beta_{6} \mathrm{D}_{\mathrm{it}}+\mathrm{v}_{\mathrm{it}} \ldots \ldots
\end{aligned}
$$

$\Delta \operatorname{Ln} \mathrm{w}_{\mathrm{it}}=\beta_{\mathrm{o}}+\beta_{1} \Delta \mathrm{Ln} \mathrm{w}_{\mathrm{it}-\mathrm{1}}+\beta_{2} \Delta \mathrm{Ln} \mathrm{L} \mathrm{L}_{\mathrm{it}}+$

$$
\begin{aligned}
& \beta_{3} \Delta \operatorname{Ln} \mathrm{L}_{\mathrm{it}-1}+\beta_{4} \Delta \operatorname{Ln} \mathrm{Q}_{\mathrm{it}}+ \\
& \beta_{5} \Delta \mathrm{LnQ}_{\mathrm{it}-1}+\beta_{6} \mathrm{D}_{\mathrm{it}}+\mathrm{u}_{\mathrm{it}}
\end{aligned}
$$

dimana $\mathrm{D}$ adalah variabel dummy

$\mathrm{D}=0$ untuk periode 1998 (periode sebelum penurunan tarif)

$\mathrm{D}=1$ untuk periode 1998 (periode sesudah penurunan tarif)

i menunjukkan industri

$\mathrm{t}$ menunjukkan periode/tahun
Dari persamaan (6) dan (7), maka variabel $L$ dan $w$ menjadi variabel dependen, tetapi pada saat bersamaan menjadi variabel independen pada persamaan lain sehingga terdapat kemungkinan hubungan kausalitas antara L dan $\mathrm{w}$, sehingga perlu dilakukan pengujian kausalitas. Pengujian kausalitas antara $\mathrm{L}$ dan $\mathrm{w}$ menggunakan uji kausalitas Granger.

$\operatorname{Ln} L_{i t}=\alpha_{0}+\sum \alpha_{m} \operatorname{Ln} L_{i t, m}+\sum \alpha_{n} L n W_{i t, n}+u_{i t}$

$\operatorname{Ln} W_{i t}=\beta_{0}+\sum \beta_{m} \operatorname{Ln} W_{i t, m}+\sum \beta_{n} L n L_{i t, n}+u_{i t}$

Bila nilai $\alpha_{\mathrm{n}}$ dan $\beta_{\mathrm{n}}$ berbeda dengan nol, mengindikasikan adanya hubungan kausalitas antara variabel $L$ dan $w$, sehingga persamaan (6) dan (7) merupakan persamaan simultan. Sebaliknya bila tidak terdapat hubungan kausalitas antara variabel $\mathrm{L}$ dan $\mathrm{w}$, maka persamaan (6) dan (7) dapat diestimasi sebagaimana persamaan tunggal.

Salah satu anggapan dalam ekonometri adalah stasioneritas variabel yang akan diestimasi. Untuk mengetahui stasioner tidaknya data, digunakan pengujian akar-akar unit dalam panel data. Pengujian dilakukan sesuai prosedur yang diajukan Levin dan Lin (1992) yang berupaya memasukkan unsur heterogenitas lintas tempat dalam pengujian akar-akar unit.

\section{Dampak jangka pendek dan jangka panjang}

Perubahan pada sisi produksi akan memiliki dampak pada employment dan upah. 
Perubahan employment dari sektor industri manufaktur $j$ dapat dituliskan sebagai

$$
\frac{d \ln L_{j}}{d \operatorname{Ln} Q_{j}}=\frac{\delta \operatorname{Ln} L_{j}}{\delta \operatorname{Ln} Q_{j}}+\frac{\delta \operatorname{Ln} L_{j}}{\delta \operatorname{Ln} w_{j}} \times \frac{\delta \operatorname{Ln} w_{j}}{\delta \operatorname{Ln} Q_{j}}
$$

Sedangkan perubahan upah dari sektor industri manufaktur $\mathrm{j}$ dapat dituliskan

$$
\frac{d \operatorname{Ln} w_{j}}{d \operatorname{Ln} Q_{j}}=\frac{\delta \operatorname{Ln} w_{j}}{\delta \operatorname{Ln} Q_{j}}+\frac{\delta \operatorname{Ln} w_{j}}{\delta \operatorname{Ln} L_{j}}+\frac{\delta \operatorname{Ln} L_{j}}{\delta \operatorname{Ln} Q_{j}}
$$

\section{Variabel operasional}

Teori ekonomi sering kali tidak terlalu jelas dalam menjelaskan definisi dan pengukuran variabel. Dalam penelitian empiris definisi dan cara pengukuran data dari variabel yang diamati harus bersifat operasional agar tujuan penelitian dapat dicapai (Insukindro, 1992: 14).

Definisi operasional variabel yang digunakan adalah

- Tingkat employment merupakan jumlah pekerja produksi dan non produksi yang bekerja pada industri manufaktur dan dinyatakan dalam satuan ribu orang.

- Output merupakan nilai output industri manufaktur dan dinyatakan dalam satuan juta rupiah pada harga konstan 1993.

- Upah adalah pengeluaran untuk pekerja yang mencakup upah pokok dan tunjangan dibagi dengan jumlah pekerja dan dinyatakan pada harga konstan 1993.

\section{HASIL DAN PEMBAHASAN}

\section{Hasil Estimasi}

Untuk mengetahui apakah persamaan (6) dan (7) merupakan persamaan simultan atau bukan dilakukan uji kausalitas Granger. Hasil pengujian kausalitas Granger menunjukkan tidak adanya hubungan kausalitas antara variabel $L$ dan $w$. Dengan demikian persamaan (6) dan (7) dapat diestimasi sebagaimana persamaan tunggal. Hasil pengujian kausalitas tercantum pada lampiran.

Pengujian akar-akar unit dilakukan untuk data diferensiasi pertama dengan prosedur vektor autoregresif yang memasukkan variabel senjang (lag) sebanyak 2 ke belakang. Hasil pengujian akar-akar unit menunjukkan bahwa semua variabel mencapai stasioner pada diferensiasi tingkat pertama. Hasil pengujian akar-akar unit terlihat seperti pada tabel berikut.

Tabel 1. Hasil Pengujian Akar-akar Unit

\begin{tabular}{ccc}
\hline Variabel & t-test & $\begin{array}{c}\text { Nilai kritis t untuk } \\
\text { N=100 pada } \alpha=5 \%\end{array}$ \\
\hline$Q$ & $-3,140110$ & $-1,69$ \\
L & $-2,146037$ & $-1,69$ \\
w & $-1,987321$ & $-1,69$ \\
\hline
\end{tabular}

Sumber : Lampiran

Selanjutnya berdasar persamaan employment dilakukan analisis regresi dengan bantuan program Eviews 4. Hasil analisis terlihat seperti pada tabel 2 berikut. 
Tabel 2. Hasil Estimasi Berdasar Persamaan Employment

\begin{tabular}{lccl}
\hline variabel & Koefisien & t-statistik & Signifikasi \\
\hline$\Delta \operatorname{Ln} L_{i t-1}$ & $-0,2546$ & $-3,7016$ & 0,0004 \\
$\Delta \operatorname{Ln} W_{i t}$ & $-0,0851$ & $-3,6911$ & 0,0004 \\
$\Delta \operatorname{Ln} W_{i-1}$ & $-0,0064$ & $-2,0322$ & 0,0450 \\
$\Delta \operatorname{Ln} Q_{i t}$ & 0,0332 & 2,3002 & 0,0237 \\
$\Delta \operatorname{Ln} Q_{i-1}$ & $-0,0022$ & $-0,2968$ & 0,7673 \\
Dum & 0,0204 & 2,8888 & 0,0048 \\
\hline
\end{tabular}

Sumber : Lampiran 2.

Berdasar hasil estimasi pada tabel 2, maka hampir semua variabel signifikan secara statistik kecuali variabel $\Delta \mathrm{Ln} \mathrm{Q}_{\mathrm{it}-1}$. Oleh karena variabel $\Delta \mathrm{Ln} \quad \mathrm{Q}_{\text {it-1 }}$ tidak signifikan, maka variabel ini tidak berpengaruh terhadap tingkat employment. Variabel dummy yang signifikan secara statistik, menunjukkan bahwa liberalisasi perdagangan yang dimulai tahun 1998 berpengaruh terhadap tingkat employment industri manufaktur padat karya.

Sedangkan hasil estimasi persamaan upah terlihat seperti pada tabel 3. berdasar model ini, maka semua variabel independen signifikan secara statistik. Demikian pula variabel dummy yang signifikan secara statistik, menunjukkan bahwa liberalisasi perdagangan yang dimulai tahun 1998 berpengaruh terhadap tingkat upah industri manufaktur padat karya. Dengan signifikannya variabel dummy berarti dapat dilakukan analisis dampak liberalisasi perdagangan/penurunan tarif terhadap tingkat employment dan upah pekerja industri manufaktur padat karya baik jangka pendek dan jangka panjang.
Tabel 3. Hasil Estimasi Berdasar Persamaan Upah

Variabel Koefisien t-Statistik Signifikasi

$\begin{array}{lrrr}\Delta \Delta \operatorname{Ln} W_{\text {it-1 }} & -0,2162 & -7,8712 & 0,0000 \\ \Delta \operatorname{Ln} \text { Lit } & -0,1023 & -30,3377 & 0,0000 \\ \Delta \operatorname{Ln} \text { Lit- } & 0,0771 & 30,4972 & 0,0000 \\ \Delta \operatorname{Ln} Q_{\text {it }} & 0,1049 & 40,3313 & 0,0000 \\ \Delta \operatorname{Ln} Q_{i-1} & -0,0330 & -5,3387 & 0,0000 \\ \text { Dum } & -0,0779 & -35,7405 & 0,0000\end{array}$

Sumber. Lampiran 3

\section{Pengujian Hipotesis}

Liberalisasi perdagangan akan berdampak terhadap kinerja (tingkat output) industri manufaktur padat karya. Tingkat output industri ini akan berpengaruh terhadap permintaan faktor produksi tenaga kerja. Perubahan permintaan tenaga kerja akan berdampak terhadap tingkat employment dan upah pekerja. Selanjutnya dampak liberalisasi perdagangan terhadap tingkat employment dan upah pekerja akan dianalisis berdasar persamaan (10) dan (11).

Dampak liberalisasi perdagangan terhadap tingkat employment dan upah pekerja industri manufaktur padat karya terlihat pada tabel 4 berikut. 
Tabel 4. Dampak Liberalisasi Perdagangan terhadap Tingkat Employment dan Upah Pekerja Industri Manufaktur Padat Karya

\begin{tabular}{lcc}
\hline $\begin{array}{l}\text { Dampak Liberalisasi } \\
\text { Terhadap }\end{array}$ & $\begin{array}{l}\text { Jangka } \\
\text { Pendek }\end{array}$ & $\begin{array}{c}\text { Jangka } \\
\text { Panjang }\end{array}$ \\
\hline Tingkat Employment & 0,02708 & 0,02662 \\
Upah & 0,0685 & 0,0710 \\
\hline
\end{tabular}

Sumber: Lampiran 4.

Dalam jangka pendek, liberalisasi perdagangan akan menaikkan tingkat employment dan upah pekerja industri manufaktur. Kenaikan upah pekerja setelah liberalisasi perdagangan berbeda dengan hipotesis penelitian yang menyatakan liberalisasi perdagangan, dalam jangka pendek, akan menaikkan tingkat employment dan menurunkan upah pekerja industri manufaktur. Keadaan ini diduga karena terjadinya perubahan dalam sistem hubungan industrial di Indonesia dengan adanya ratifikasi terhadap konvensi ILO nomor 87 tahun 1948 yang memberikan kebebasan berserikat dan perlindungan hak-hak pekerja untuk berorganisasi. Ratifikasi ini didukung dengan disahkannya Undang-undang No.21 tahun 2000 yang memberikan jaminan dan kemudahan bagi pekerja untuk membentuk serikat pekerja. Sistem hubungan industrial berubah dari sistem yang sangat terpusat dan dikendalikan penuh oleh pemerintah pusat ke sistem yang terdesentralisasi. Dalam sistem baru ini, pekerja memiliki kekuatan tawar (bargaining power) yang lebih tinggi dalam perundingan mengenai tingkat upah. Di samping Pemerintah menetapkan tingkat upah minimum (minimum wage) yang lebih tinggi daripada tingkat upah pasar yang tingkat upah akan sulit untuk turun.
Penurunan tingkat upah juga tidak disukai bukan saja oleh oleh pengusaha (Blinder dan Choi, 1990; Agell dan Lundborg, 1995 ; Bewley, 1997; Champbel dan Kamlani, 1997). Peneliti-peneliti tersebut menyatakan bahwa pengusaha tidak memperoleh keuntungan dari tingkat upah yang lebih rendah (Bewley, 1995). Penurunan upah berdampak buruk terhadap moral pekerja (partisipasi, kejujuran dan kerjasama) yang akan membawa dampak negatif bagi kinerja perusahaan (Bewley, 1997).

Dalam jangka panjang, liberalisasi perdagangan akan berlangsung seperti yang diprediksi oleh teori Stolper-Samuelson. Dengan barang ekspor yang relatif padat tenaga kerja, penurunan tarif akan menaikkan permintaan terhadap barang produksi yang padat karya sehingga output industri padat karya naik. Kenaikan output memerlukan jumlah tenaga kerja yang lebih banyak sehingga permintaan tenaga kerja naik dan diikuti kenaikan tingkat upah (Markusen dkk, 1995; 109). Di samping itu, faktor produksi modal dapat bergerak antar sektor sehingga jumlah modal akan bertambah. Kenaikan jumlah modal ini akan meningkatkan produk marjinal tenaga kerja sehingga meningkatkan tingkat upah (Haouas, dkk, 2002).

\section{SIMPULAN}

Liberalisasi perdagangan yang berupa penurunan tariff akan meningkatkan tingkat employment dan upah pekerja industri padat karya baik dalam jangka pendek maupun jangka panjang. Kenaikan output menyebabkan permintaan tenaga kerja naik dan diikuti kenaikan tingkat employment dan upah pekerja. Di samping itu, dalam jangka panjang faktor produksi modal dapat 
bergerak antar sektor sehingga jumlah modal akan bertambah. Kenaikan jumlah modal ini akan meningkatkan produk marjinal tenaga kerja sehingga meningkatkan tingkat upah.

\section{KETERBATASAN}

Penelitian ini memiliki keterbatasan berikut.

a. Penelitian ini tidak membedakan pekerja industri manufaktur berdasar keahlian/ pendidikan dan jabatan strukturalnya.

b. Penelitian ini membahas dampak reformasi nilai tukar dan laju inflasi Indonesia yang akan berdampak terhadap pola perdagangan.

\section{KEPUSTAKAAN}

Agell, J., dan P. Lundborg, 1995. “Theories of Pay and Unemployment: Survey Evidence from Swedish Manufacturing Firm," Scandinavian Journal of Economics, 97

Arbache, Jorge Saba 2001, "Trade Liberalization and Labour Markets in Developing Countries: Theory and Evidence", Texto Para Discussão $N^{\circ}$ 853, University of Brasilia and University of Kent at Canterbury.

Badan Pusat Statistik, Statistik Industri, Jakarta, beberapa edisi

Baltagi, Badi H., 2001. Econometric of Panel Data, Second Edition, John Wiley and Sons Ltd.

Bewley, 1997, Why Wages Don't Fall During a Recession, Harvard University Press.

Bewley, T.F., 1995, “A Depressed Labour Market as Explained by Participant", American Economic Review", 85.
Beyer, H., P. Rojas dan R. Vergara, 1999. "Trade Liberalization and Wage in Equality", Journal of Development Economics, Vol. 59.

Blinder, A., dan DD. Choi, 1990. "A Shred of Evidence on Theories of Wage Stickiness," Quarterly Journal of Economics, 105

Campbell, C., dan K. Kamlani, 1997. " The Reason for Wage Rigidity: Evidence from a Survey of Firms," Quarterly Journal of Economics, 112

Departemen Luar Negeri, 2003, Sekilas WTO, Jakarta.

Edward, 1988. "Term of Trade, Tariff and Labor Market Adjustment in Developing Countries", World Bank Economic Review, vol.2

Haouas, Ilham, M., Yagoubi dan A., Heshmati, 2002, "The Impact of Trade Liberalization on Employment and Wage in Tunisian Industries", Discussion Paper No. 2002/102, United Nation University.

Hsiao, C. (1986). Analysis of Panel Data, Econometric Society Monographs, No 11.

Insukindro. 1992. "Pembentukan Model dalam Penelitian Ekonomi”, Jurnal Ekonomi dan Bisnis Indonesia, Vol. 7.

Kim, J. W., 1984. "CES Production Function in Manufacturing and Problems of Industrialization in LDCs", Economic Development and Cultural change, Vol.33

Lee, 1999. "Wage and Employment in China, 1980-1995: Corporatization, Market Development and Insider 
Force", Journal of Comparative Economy, vol.27

Levin, A. dan Lin, C. F., 1992. "Unit Root Tests in Panel Data: Asymptotic and Finite Sample Properties", Discussion Paper No. 92-93, University of California at San Diego.

Levinson, 1999. "Employment Responses to Liberalization in Chili", Journal of International Economic Vo. 27.

Markusen, R. James, J.R., Melvin, W. H Kaemdfer and K. E., Markus, 1995, "International Trade: Theory and Evidence", McGraw Hill

Poot, Hubib, A., Kuyvenhen dan J. C. Jansen, 1992, "Industrialization and Trade in Indonesia", Yogyakarta: Gadjah Mada University Press.

Robbins, D. J., 1994. "Worsening Relative Wage Dispersion in Chile During Trade Liberalization, and Its Causes: Is Supply at Fault?" Development Discussion Papers No. 484, Harvard Institute for International Development.
. 1995, "Wage Dispersion and Trade in Colombia: an Analysis of Greater Bogota: 1876-1989" Harvard University: Harvard Institute goes International Development, mimeo.

Robbins, D. J., dan T. H Gindling, 1999. "Trade Liberalization and the Relative Wages for More-skilled Workers in Costa Rica", Review of Development Economics, vol. 3.

Setiaji, Bambang, 2001. "Sumber-sumber Perbedaan Upah antar Industri pada Tenaga kerja Produksi dan Non Produksi di Indonesia", Disertasi, UGM.

Soediyono, 1990. Tinjauan Sekilas Berbagai Sistem Devisa yang Pernah Digunakan Indonesia, Pidato Pengukuhan Guru Besar, UGM, Yogyakarta.

Wood, A. (1994), North-South Trade, Employment and Inequality, Clarendon Press: Oxford. 


\section{Hasil Pengujian Kausalitas Granger}

Pairwise Granger Causality Tests

Date: 10/06/05 Time: 05:07

Sample: 19902002

Lags: 2

\begin{tabular}{lccc}
\hline \hline Null Hypothesis: & Obs & F-Statistic & Probability \\
\hline W_31151 does not Granger Cause L_31151 & 11 & 0.00189 & 0.99812 \\
L_31151 does not Granger Cause W_31151 & & 1.49784 & 0.29672 \\
\hline \hline
\end{tabular}

Pairwise Granger Causality Tests

Date: 10/06/05 Time: 05:09

Sample: 19902002

Lags: 2

\begin{tabular}{lccc}
\hline Null Hypothesis: & Obs & F-Statistic & Probability \\
\hline \hline W_31181 does not Granger Cause L_31181 & 11 & 1.57946 & 0.28114 \\
L_31181 does not Granger Cause W_31181 & & 0.28495 & 0.76169 \\
\hline
\end{tabular}

Pairwise Granger Causality Tests

Date: 10/06/05 Time: 05:14

Sample: 19902002

Lags: 2

\begin{tabular}{lccc}
\hline Null Hypothesis: & Obs & F-Statistic & Probability \\
\hline \hline W_31221 does not Granger Cause L_31221 & 11 & 0.06030 & 0.94205 \\
L_31221 does not Granger Cause W_31221 & & 0.47374 & 0.64413 \\
\hline \hline
\end{tabular}

Pairwise Granger Causality Tests

Date: 10/06/05 Time: 05:16

Sample: 19902002

Lags: 2

\begin{tabular}{lccc}
\hline \hline Null Hypothesis: & Obs & F-Statistic & Probability \\
\hline \hline W_31410 does not Granger Cause L_31410 & 11 & 0.61424 & 0.57189 \\
L_31410 does not Granger Cause W_31410 & & 0.65524 & 0.55286 \\
\hline
\end{tabular}

Pairwise Granger Causality Tests

Date: 10/06/05 Time: 05:17

Sample: 19902002

Lags: 2

\begin{tabular}{lccc}
\hline Null Hypothesis: & Obs & F-Statistic & Probability \\
\hline \hline W_31420 does not Granger Cause L_31420 & 11 & 1.58189 & 0.28069 \\
L_31420 does not Granger Cause W_31420 & & 1.03288 & 0.41164 \\
\hline
\end{tabular}


Pairwise Granger Causality Tests

Date: 10/06/05 Time: 05:18

Sample: 19902002

Lags: 2

\begin{tabular}{lccc}
\hline \hline Null Hypothesis: & Obs & F-Statistic & Probability \\
\hline \hline W_32111 does not Granger Cause L_32111 & 11 & 5.23502 & 0.04835 \\
L_32111 does not Granger Cause W_32111 & & 0.92391 & 0.44690 \\
\hline \hline
\end{tabular}

Pairwise Granger Causality Tests

Date: 10/06/05 Time: 05:19

Sample: 19902002

Lags: 2

\begin{tabular}{lccc}
\hline \hline Null Hypothesis: & Obs & F-Statistic & Probability \\
\hline \hline W_32114 does not Granger Cause L_32114 & 11 & 4.66078 & 0.06005 \\
L_32114 does not Granger Cause W_32114 & & 3.09358 & 0.11933 \\
\hline \hline
\end{tabular}

Pairwise Granger Causality Tests

Date: 10/06/05 Time: 05:20

Sample: 19902002

Lags: 2

\begin{tabular}{lccc}
\hline \hline Null Hypothesis: & Obs & F-Statistic & Probability \\
\hline \hline W_32130 does not Granger Cause L_32130 & 11 & 1.73331 & 0.25461 \\
L_32130 does not Granger Cause W_32130 & & 0.66919 & 0.54658 \\
\hline \hline
\end{tabular}

Pairwise Granger Causality Tests

Date: 10/06/05 Time: 05:21

Sample: 19902002

Lags: 2

\begin{tabular}{lccc}
\hline \hline Null Hypothesis: & Obs & F-Statistic & Probability \\
\hline \hline W_32210 does not Granger Cause L_32210 & 11 & 0.64868 & 0.55585 \\
L_32210 does not Granger Cause W_32210 & & 0.54986 & 0.60358 \\
\hline \hline
\end{tabular}

Pairwise Granger Causality Tests

Date: 10/06/05 Time: 05:22

Sample: 19902002

Lags: 2

\begin{tabular}{lccc}
\hline \hline Null Hypothesis: & Obs & F-Statistic & Probability \\
\hline \hline W_33113 does not Granger Cause L_33113 & 11 & 2.91964 & 0.13016 \\
L_33113 does not Granger Cause W_33113 & & 0.30459 & 0.74819 \\
\hline \hline
\end{tabular}




\section{Hasil Estimasi}

Dependent Variable: DLL?

Method: GLS (Cross Section Weights)

Date: 10/02/05 Time: 12:15

Sample: 19922002

Included observations: 11

Number of cross-sections used: 10

Total panel (balanced) observations: 110

One-step weighting matrix

White Heteroskedasticity-Consistent Standard Errors \& Covariance

\begin{tabular}{|c|c|c|c|c|}
\hline Variable & Coefficient & Std. Error & t-Statistic & Prob. \\
\hline $\begin{array}{c}\text { DLL1? } \\
\text { DLW? } \\
\text { DLW1? } \\
\text { DLQ? } \\
\text { DLQ1? } \\
\text { DUM? } \\
\text { Fixed Effects } \\
\text {-31151-C } \\
31181-C \\
-31221-C \\
-31410-C \\
31420-C \\
-32111-C \\
32114-C \\
-32130-C \\
32210-C \\
33113-C \\
\end{array}$ & $\begin{array}{r}-0.254574 \\
-0.085069 \\
-0.006466 \\
0.033263 \\
-0.002233 \\
0.020406 \\
\\
0.013074 \\
0.015246 \\
-0.028361 \\
0.006237 \\
0.045014 \\
0.078288 \\
-0.180472 \\
0.228273 \\
-0.011127 \\
-0.006591 \\
\end{array}$ & $\begin{array}{l}0.068773 \\
0.023047 \\
0.003182 \\
0.014461 \\
0.007525 \\
0.007064\end{array}$ & $\begin{array}{r}-3.701655 \\
-3.691048 \\
-2.032223 \\
2.300171 \\
-0.296805 \\
2.888741\end{array}$ & $\begin{array}{l}0.0004 \\
0.0004 \\
0.0450 \\
0.0237 \\
0.7673 \\
0.0048\end{array}$ \\
\hline \multicolumn{5}{|c|}{ Weighted Statistics } \\
\hline $\begin{array}{l}\text { R-squared } \\
\text { Adjusted R-squared } \\
\text { S.E. of regression } \\
\text { Log likelihood } \\
\text { Durbin-Watson stat } \\
\end{array}$ & $\begin{array}{l}0.238997 \\
0.117561 \\
0.326984 \\
23.78213 \\
2.067521 \\
\end{array}$ & $\begin{array}{l}\text { Mean dependent var } \\
\text { S.D. dependent var } \\
\text { Sum squared resid } \\
\text { F-statistic } \\
\text { Prob(F-statistic) } \\
\end{array}$ & & $\begin{array}{l}0.058159 \\
0.348084 \\
10.05033 \\
1.968082 \\
0.025767 \\
\end{array}$ \\
\hline \multicolumn{5}{|c|}{ Unweighted Statistics } \\
\hline $\begin{array}{l}\text { R-squared } \\
\text { Adjusted R-squared } \\
\text { S.E. of regression } \\
\text { Durbin-Watson stat }\end{array}$ & $\begin{array}{l}0.144624 \\
0.008128 \\
0.338024 \\
2.283108\end{array}$ & $\begin{array}{l}\text { Mean dependent var } \\
\text { S.D. dependent var } \\
\text { Sum squared resid }\end{array}$ & & $\begin{array}{l}0.019661 \\
0.339406 \\
10.74046\end{array}$ \\
\hline
\end{tabular}


Dependent Variable: DLW?

Method: Seemingly Unrelated Regression

Date: 10/02/05 Time: $12: 43$

Sample: 19922002

Included observations: 11

Number of cross-sections used: 10

Total panel (balanced) observations: 110

One-step weighting matrix

\begin{tabular}{ccccc}
\hline \hline Variable & Coefficient & Std. Error & t-Statistic & Prob. \\
\hline \hline DLW1? & -0.216228 & 0.027471 & -7.871208 & 0.0000 \\
DLL? & -0.102575 & 0.003381 & -30.33771 & 0.0000 \\
DLL1? & 0.077099 & 0.002528 & 30.49717 & 0.0000 \\
DLQ? & 0.104860 & 0.002600 & 40.33130 & 0.0000 \\
DLQ1? & -0.033003 & 0.006182 & -5.338730 & 0.0000 \\
DUM? & -0.077956 & 0.002181 & -35.74050 & 0.0000 \\
Fixed Effects & & & & \\
-31151-C & -0.000579 & & & \\
-31181-C & 0.066295 & & & \\
-31221--C & 0.084902 & & & \\
-31410-C & 0.074692 & & & \\
-31420-C & 0.156637 & & & \\
-32111-C & 0.038805 & & & \\
-32114-C & 0.124159 & & & \\
-32130-C & 0.061800 & & & \\
-32210-C & 0.033461 & & & \\
-33113-C & 0.071454 & & & \\
\hline Weighted Statistics & & & & \\
\hline \hline Log likelihood & 96.57121 & & & \\
\hline \hline Unweighted Statistics & & & & \\
\hline \hline R-squared & 0.192951 & & \\
Adjusted R-squared & 0.064167 & S.D. dependent var & \\
S.E. of regression & 0.308427 & Sum squared resid & \\
Durbin-Watson stat & 2.296592 & & & \\
\hline \hline
\end{tabular}

Dampak Liberalisasi Perdagangan terhadap Tingkat Employment dan Upah Pekerja Industri Manufaktur Padat Karya

\section{Tingkat Employment}

○ Jangka pendek

$$
\frac{d L n L}{d L n Q_{j}}=(0,0332)+(-0,0851)(0,1049-0,0330)=0,02708
$$




\section{○ Jangka panjang}

$$
\frac{d \operatorname{Ln}}{\mathrm{dLnQ}_{\mathrm{j}}}=(0,0332)+(-0,0851-0,0064)(0,1049-0,0330)=0,02662
$$

\section{Tingkat Upah}

○ Jangka pendek

$$
\frac{d \operatorname{Ln} L}{d L n Q_{j}}=(0,1049-0,0330)+(-0,1023)(0,0332)=0,0685
$$

○ Jangka panjang

$$
\frac{\mathrm{dLnL}}{\mathrm{dLnQ}_{\mathrm{j}}}=(0,1049-0,0330)+(-0,1023+0,0771)(0,0332)=0,0710
$$

Pool unit root test: Summary

Date: 12/07/05 Time: 12:24

Sample: 19902002

Series: L_31151, L_31181, L_31221, L_31410, L_31420, L_32111, L_32114, L_32130, L_33111, L_33113

Exogenous variables: Individual effects

Automatic selection of maximum lags

Automatic selection of lags based on SIC: 0

\begin{tabular}{|c|c|c|c|c|}
\hline Method & Statistic & Prob. ${ }^{*}$ & $\begin{array}{c}\text { Cross- } \\
\text { sections }\end{array}$ & Obs \\
\hline \multicolumn{5}{|c|}{ Null: Unit root (assumes common unit root process) } \\
\hline Levin, Lin \& Chu $t^{\star}$ & -1.29581 & 0.0975 & 10 & 120 \\
\hline Breitung t-stat & 0.14991 & 0.5596 & 10 & 110 \\
\hline \multicolumn{5}{|c|}{ Null: Unit root (assumes individual unit root process) } \\
\hline Im, Pesaran and Shin W-stat & -1.28354 & 0.0997 & 10 & 120 \\
\hline ADF - Fisher Chi-square & 32.2564 & 0.0406 & 10 & 120 \\
\hline PP - Fisher Chi-square & 32.3265 & 0.0399 & 10 & 120 \\
\hline \multicolumn{5}{|c|}{ Null: No unit root (assumes common unit root process) } \\
\hline Hadri Z-stat & 5.82645 & 0.0000 & 10 & 130 \\
\hline
\end{tabular}

Newey-West bandwidth selection using Bartlett kemel

Balanced observations for each test

** Probabilities for Fisher tests are computed using an asympotic Chi-square distribution. All other tests assume asymptotic normality. 
Pool unit root test: Summary

Date: 12/07/05 Time: 12:29

Sample: 19902002

Series: Q_31151, Q_31181, Q_31221, Q_31410, Q_31420, Q_32111, Q_32114, Q_32130, Q_33111, Q_33113

Exogenous variables: Individual effects

Automatic selection of maximum lags

Automatic selection of lags based on SIC: 0 to 2

Newey-West bandwidth selection using Bartlett kemel

\begin{tabular}{lcccc}
\hline \hline Method & Statistic & Prob. $^{* *}$ & $\begin{array}{c}\text { Cross- } \\
\text { sections }\end{array}$ & Obs \\
\hline Null: Unit root (assumes common unit roct process) & & & \\
\hline Levin, Lin \& Chu $t^{*}$ & 0.34540 & 0.6351 & 10 & 112 \\
Breitung t-stat & -1.68646 & 0.0459 & 10 & 102
\end{tabular}

Null: Unit root (assumes individual unit root process)

\begin{tabular}{lcccc}
\hline Im, Pesaran and Shin W-stat & -0.33059 & 0.3705 & 10 & 112 \\
ADF - Fisher Chi-square & 28.6051 & 0.0958 & 10 & 112 \\
PP - Fisher Chi-square & 22.6781 & 0.3049 & 10 & 120 \\
& & & & \\
Null: No unit root (assumes common unit root process) & & 10 & 130 \\
\hline Hadri Z-stat & 3.88216 & 0.0001 & 10 \\
\hline
\end{tabular}

** Probabilities for Fisher tests are computed using an asympotic Chi-square distribution. All other tests assume asymptotic normality.

Pool unit root test: Summary

Date: 12/07/05 Time: $12: 30$

Sample: 19902002

Series: W_31151, W_31181, W_31221, W_31410, W_31420, W_32111, W_32114, W_32130, W_33111, W_33113

Exogenous variables: Individual effects

Automatic selection of maximum lags

Automatic selection of lags based on SIC: 0 to 1

Newey-West bandwidth selection using Bartlett kernel

\begin{tabular}{|c|c|c|c|c|}
\hline Method & Statistic & Prob. ** & $\begin{array}{l}\text { Cross- } \\
\text { sections }\end{array}$ & Obs \\
\hline \multicolumn{5}{|c|}{ Null: Unit root (assumes common unit root process) } \\
\hline Levin, Lin \& Chu $\mathbf{t}^{\star}$ & -14.7555 & 0.0000 & 10 & 117 \\
\hline Breitung t-stat & -2.13138 & 0.0165 & 10 & 107 \\
\hline \multicolumn{5}{|c|}{ Null: Unit root (assumes individual unit root process) } \\
\hline Im, Pesaran and Shin W-stat & -6.88954 & 0.0000 & 10 & 117 \\
\hline ADF - Fisher Chi-square & 66.4195 & 0.0000 & 10 & 117 \\
\hline PP - Fisher Chi-square & 63.7020 & 0.0000 & 10 & 120 \\
\hline
\end{tabular}


Null: No unit root (assumes common unit root process)

Hadri Z-stat 3.81457

0.0001

10 130

** Probabilities for Fisher tests are computed using an asympotic Chi- -square distribution. All other tests assume asymptotic normality. 